\title{
Indonesia: The Dangers of Democratic Regression
}

\author{
Edward Aspinall \\ Australian National University \\ Eve Warburton \\ Australian National University
}

\begin{abstract}
For the last decade, comparativists and country experts have praised Indonesia's democratic stability. Free, fair and highly competitive elections are held regularly throughout the country. Indonesia boasts a vibrant civil society and its press is amongst the freest in the region. However, praise for Indonesia's democratic credentials has always been accompanied by significant caveats. Analysts point to systemic corruption and weak rule of law, and conclude that while Indonesia's democracy is stable, it continues to lag on many indicators for democratic quality. In this paper, we reassess the health of Indonesian democracy and point to new signs of fragility and, in some cases, democratic deterioration. Specifically, we look at the rise of a xenophobic and reactionary brand of populist politics, and a sustained illiberal drift in the regulation of civil liberties. We also use polling data to investigate the depth of societal support for democratic institutions and values. The data reveal that, although support for democracy as an abstract value remains high, there is also significant potential for an illiberal coalition that could provide the base for future erosion of democratic institutions
\end{abstract}

Keywords: Reformasi, democratic regression, populist, democratic fragility

\section{INTRODUCTION}

In 1998 Indonesia will celebrate the twenty-year anniversary of the downfall of Soeharto's "New Order" regime and the beginning of the process of reformasi. For much of that period, but especially for the last decade, comparativists and country experts have praised Indonesia's democratic stability. Free, fair and highly competitive elections are held regularly throughout the country. Indonesia boasts a vibrant civil society and its press is amongst the freest in the region. Compared to other postauthoritarian polities, Indonesia's democracy appears robust, and we do not find the sort of democratic deterioration seen in countries such as Thailand or the Philippines. Writing after Indonesia's second direct presidential elections in 2009 [1], applauded Indonesia for achieving the status of a "stable democracy - with no obvious threats or potent anti-democratic challenges on the horizon." Diamond also described Indonesia back then as, "a relatively liberal democracy."Most analysts continue to see Indonesia as a comparatively 'healthy' democratic bastion, in which public support for democratic government remains amongst the highest and most stable in the East Asian region [2].

Praise for Indonesia's democratic credentials has always been accompanied by significant caveats. Analysts point to systemic corruption and weak rule of law, and conclude that while Indonesia's democracy is stable, it continues to lag on many indicators for democratic quality [3][4]. A cast of authoritarian-era elites dominate the political landscape, and continue to pursue anti-reformist agendas [3][4][5]. Overall, however, even the most critical observers have been relatively sanguine about Indonesia's democratic trajectory. Throughout the Susilo Bambang Yudhoyono presidency (2004-2014), few analysts seriously entertained the notion of authoritarian regression. Mietzner, for example, argued that attempts by anti-reformist elites to undermine Indonesian democracy have largely been checked, "by resistance from a strong civil society" [4], and continued support amongst the Indonesian public for their country's democratic institutions [6][7]. So despite suffering low democratic quality, most analysts agreed that Indonesia's democracy was now stable (if stagnant), relatively liberal, and faced no serious existential threats.

Events and trends since 2014, however, have cast doubt upon this analytical consensus. In this paper, we reassess the health of Indonesian democracy and point to new signs of fragility and, in some cases, democratic deterioration. Specifically, we look at the rise of a xenophobic and reactionary brand of populist politics, and a sustained illiberal drift in the regulation of civil liberties. We also use polling data to investigate the depth of societal support for democratic institutions and values. The data reveal that, although support for democracy as an abstract value remains high, there is also significant potential for an illiberal coalition that could provide the base for future erosion of democratic institutions.

The paper is divided into three parts. In the first section, we briefly summarise the rise of a nativist and sectarian brand of political populism; in the second we analyse potential bases of support for the nascent trends of democratic backsliding that we identify; in the third we speculate on the sources of these challenges.

\section{THE POPULIST CHALLANGE}

One of the defining characteristics of the wave of democratic regression that has been taking place worldwide over the last decade or so is that threats to democracy now largely emanate from inside rather than outside of democratic governments. Events like the recent coups in Thailand, in which authoritarian actors move to overthrow a country's democratic system and suspend its constitutional order, are now relatively rare. A much more common pattern of democratic regression occurs when a 
democratically elected leader, often one promising strong and decisive leadership, gradually narrows the space for democratic opposition, bends democratic institutions to his (or her) will and gradually transforms a country into an illiberal democracy or an electoral authoritarian state. Vladimir Putin in Russia, Viktor Orbán in Hungary, or Recep Tayyip Erdoğan are among the most obvious recent examples; speculation surrounds whether elected leaders in even established democratic countries - e.g. Narendra Modi in India or Donald Trump in the United States - could achieve a similar feat.

Accordingly, we must begin by reviewing Prabowo Subianto's presidential bid in 2014. One of us has previously characterised Prabowo's campaign as a "classically authoritarian populist challenge" (Aspinall 2015, 1), which decried Indonesia's exploitation at the hands of foreign powers and corrupt political elites. Prabowo also suggested that democratic reforms, including the advent of direct elections, had gone too far. Prabowo lost by just 6 percent, bringing Indonesia within a whisper of a "severe threat of authoritarian regression" [8]. And this threat has not disappeared, with most observers confident that Prabowo will run again in the 2019 presidential elections.

Does the 2016-17 Islamist mobilisations against Jakarta's Chinese Christian governor, Basuki Tjahaja Purnama (Ahok) bear any resemblance with the Prabowo challenge, or present a similar danger to Indonesian democracy? In the lead up to the 2016 gubernatorial election, hundreds of thousands of protesters took tothe streets in Jakarta to demand that Ahok be arrested for blasphemy. Ahok had made controversial comments directing Jakartans not to listen to those who claimed the Qur'an prohibited Muslims from voting for non-Muslims. This popular mobilisation - the largest of the democratic era - was organised by a coalition of radical Islamist groups and conservative Islamic leaders and organisations, with the backing of mainstream political elites - including Prabowo, whose party sponsored the winning candidate, Anies Basweden. The sectarian campaign was highly successful: while over 70 percent of Jakartans were satisfied with Ahok's performance, only 42 percent voted for him on the day, delivering Anies a resounding victory with 58 percent of the vote [9]. Ahok, still a sitting governor, was then found guilty of blasphemy and sentenced to two years in prison. This outcome has drawn international condemnation, and demonstrates the degree of politicisation within Indonesia's judiciary [10].

There has been much debate about the depth of public support for such campaigns. Prabowo's narrow loss, and the success of the anti-Ahok campaign, suggest a significant constituency for an illiberal and reactionary brand of populist politics in Indonesia. Some analysts, however, are sceptical, and maintain that sectarian mobilisation is largely the work of opportunistic elites [11], and that we should not infer an organic rise in right-wing, Islamist sentiment amongst the electorate. Either way, such campaigns damage Indonesia's democratic fabric and, as one long-time Indonesia analyst put it, tarnish the country's reputation as "the shining example of pluralism in Southeast Asia" [10]. More generally, they indicate the potential mobilizational power of illiberal groups, and their capacity to achieve victories through the ballot box.

\section{THE ILLIBERAL DRIFT}

At the same time, and less predictably, there has been an illiberal drift in the laws and regulations governing civil liberties in Indonesia. Specifically, political manipulation of laws on defamation, treason, blasphemy, and the law on mass organisations, has all occurred, with these laws from time to time being used by political actors both within and outside of government to undermine their adversaries. There are also serious questions surrounding the protection of minority rights, particularly for religious minorities and Indonesia's LGBTI community. This drift began under President Yudhoyono, prompting a change in Indonesia's Freedom House score from 'free' to 'partly free' in 2013, and has been sustained during the first half of Joko Widowo's presidency (2014-). Jokowi won office in 2014 on a largely democratic and inclusive platform, and with the support of volunteers and a coalition of left wing and liberal civil society organisations. His campaign stood in stark contrast to the nativist and neo-authoritarian platform of his rival, Prabowo Subianto. Yet since coming to office Jokowi has pursued a conservative developmentalist agenda, and shown little concern for problems of democratic reform or human rights [12]. In some instances, the president has even used undemocratic methods to manipulate and manage sources of political opposition [9][13]. Indeed, President Jokowi has proven himself to be of a more conservative political ilk than many political commentators, and even his supporters, believed him to be. Importantly, however, most Indonesians are satisfied with the president's approach, and his approval ratings have risen steadily over the past one and a half years.

\section{MAKING SENSE OF DEMOCRATIC FRAGILITY}

These trends, we argue, indicate that Indonesia's democracy is fragile, rather than 'healthy', and may in fact be deconsolidating. But what are the sources of democratic fragility in present day Indonesia? Until now, analysts have mostly pointed to the ongoing influence of anti-reformist elites in order to explain democratic stagnation and regression [3][4][8][14]. This remains a principal cause of Indonesia's democratic fragility. But the rise in sectarian populism, and popular support for Jokowi's conservative agenda, should also prompt a more critical assessment of societal preferences, and of public commitment to core democratic values. Scholarship on democratisation emphasises that popular support is fundamental to 
democratic persistence [15]. Indeed, the literature on Indonesia specifically argues that strong and consistent public support for democracy has been an important defence against the ambitions of illiberal elites [4]. But we believe there is an urgent need for more critical examination of public opinion on support for democracy.

The Asian Barometer surveys reveal that Indonesians hold complex views about democracy and liberalism [16]. The results show that while respondents overwhelming and consistently express support for democracy as the best form of government (90 and 93 percent in 2011 and 2016 respectively), there was also a steady decline in the number of Indonesians who believe democracy is suitable for their country (80 percent in 2006, 71 percent in 2011, down to 69 percent in 2016). In 2016, only 8 percent of Indonesians believed that democracy was more important than economic development, and only 4 percent believed it was more important to protect political freedom than to reduce inequality - by far the lowest levels of support compared to other countries across the region. Indonesians demonstrate consistent and strong support for the idea that the military should govern: 32 percent in 2006 (second highest after Cambodia), 43 percent in 2011 (the highest of all countries in East Asia), and 38 percent in 2016 (third after Thailand and Myanmar, which were surveyed for the first time). The surveys also show a small but notable decrease in support for democracy over authoritarianism (from 74, to 71 and 70 percent in 2006, 2011and 2016), and a small but equally notable increase in the number of people who would sacrifice elections in return for a strong leader (from 11 to 17 percent over 2006-2015). The fourth wave survey results also demonstrate strong support for paternalistic government amongst Indonesians, and an overwhelming rejection of secularism [16]. Overall, such results suggest there is a significant constituency for illiberalism among Indonesian voters, especially but not exclusively among religiously conservative voters, and especially, but not exclusively, among urban and middle class groups.

We believe that such data point toward the potential for a broad-based illiberal coalition to pose a serious threat to
Indonesian democracy over the medium to longer term. However, the greatest danger lies not simply in the existence of such a constituency for conservative social and political values in the Indonesian electorate, but for the potential coalescence of this group with a reemergent and reinvigorated authoritarian-populist leadership from among Indonesia's old ruling caste. The 2014 presidential election, and the 2016-2017 mobilizations against Governor Ahok already indicate that such a coalition has significant mobilizational and electoral clout in Indonesia, while the experience of many other majority-Muslim countries, such as Pakistan and Malaysia point toward the anti-democratic potential of a coalition between religiously conservative social groups and authoritarian military and other elites.

\section{CONCLUSION}

Indonesia has made great progress in establishing and building a democratic system of government since the beginning of the reformasi period almost two years ago. But we believe that now is not the time for complacency. Indonesian democracy may be less secure than many observers have assumed. To be clear, we do not suggest that Indonesia is already in the midst of democratic breakdown, or that this new illiberal coalition has triumphed. Far from it. Under President Jokowi, we do not find a coherent attack upon elections, opposition parties, civic space, or an abuse of executive power [15]. We agree with Diamond, however, that analysts should pay attention to "the growing signs of fragility" in developing democracies. For Diamond, Indonesia today falls into the category of "less than liberal democracies" along with Mexico, Columbia, and Thailand (prior to the 2014 coup). These countries remain exposed to authoritarian risks and even susceptible to democratic failure [15]. Events and trends of the last three years should alert analysts to Indonesia's "illiberal turn" [10], and the real possibility of "democratic deconsolidation" [13]. Of course, this possibility remains just that - a possibility - but it is a real one, and one that is made all the more concerning because of general trends In democracy worldwide. 


\section{References}

[1] Diamond, Larry. 2009. 'Indonesia's Place in Global Democracy' in Problems of Democratisation in Indonesia: Elections, Institutions and Society edited by Edward Aspinall and Marcus Mietzner. ISEAS. Singapore.

[2] Chu et al. 2016 'Re-assessing the popular foundations of Asian democracies: Findings from four waves of the Asian Barometer Survey' Asian Barometer Working Paper Series: No. 120.

[3] Aspinall, Edward. 2010. 'The Irony of Success' Journal of DemocracyVol. 21 (2) pp.20-34.

[4] Mietzner, Marcus. 2012. 'Indonesia's Democratic Stagnation: anti-reformist elites and resilient civil society' Journal of Democratization Vol. 19 (2) pp. 209-229.

[5] Hadiz, Vedi and Richard Robison. 2004. Reorganising Power in Indonesia: The politics of oligarchy in an age of markets. Routledge.

[6] Liddle, William and Saiful Mujani. 2010. 'Personalities, Parties and Voters' Journal of Democracy Vol 21. (2) pp. 35-49

[7] Liddle, William and Saiful Mujani. 2015. 'Indonesia's Democratic Performance: A popular assessment' Japanese Journal of Political ScienceVol. 16 (2) pp. 210-226.

[8] Aspinall, Edward, Marcus Mietzner and Dirk Tomsa. 2015. 'The Moderating President: Yudhoyono's decade in power' in The Yudhoyono Presidency: Indonesia's Decade of Stability and Stagnation edited by Edward Aspinall, Marcus Mietzner and Dirk Tomsa. ISEAS. Singapore.

[9] Mietzner, Marcus. 2017. 'Ahok's Satisfied Non-voters: an anatomy' New Mandala, 5 May. Available at: http://www.newmandala.org/ahoks-satisfied-non-votersanatomy/

[10] Jones, Sidney. 2017. 'Indonesia's Illiberal Turn: after the Ahok case' Foreign Affairs, 26 May. Available at: https://www.foreignaffairs.com/articles/indonesia/2017-0526/indonesias-illiberal-turn

[11] Busch, Matthew. 2017. 'Why the Jakarta election could be bad news for Jokowi' Sydney Morning Herald. 21 April. Available at: http://www.smh.com.au/comment/why-thejakarta-election-result-could-be-bad-news-for-jokowi20170420-gvp495.html

[12] Warburton, Eve. 2016. 'Jokowi and the New Developmentalism' Bulletin of Indonesian Economic Studies Vol. 53(3) pp. 297-320.
[13] Mietzner, Marcus. Forthcoming. 'Fighting Illiberalism with Illiberalism: Islamist Populism and Democratic Deconsolidation in Indonesia'

[14] Hadiz, Vedi. 2010. Localising Power in Post-authoritarian Indonesia: a Southeast Asia perspective. Stanford University Press.

[15] Diamond, Larry. 2015. 'Facing Up to the Democratic Recession' Journal of Democracy Vol. 26 (1) pp 141-155.

[16] Huang, Kai-Ping and Bridget Welsh. 2016. 'Liberals and Conservatives: understanding political polarization in Southeast Asia.' Asian Barometer Working Paper Series No.119. 